\title{
"As soon as the sword was sheathed, the book was opened again"
}

\author{
MiRIAM GILLIS-CARLEBACH
}

School of Education, Bar-llan University, Ramat Gan, Israel

\begin{abstract}
This paper deals with the question, whether reading could be forgotten by skilled readers deprived from reading during a long period. Forty questionnaires and interviews of Israeli Holocaust survivors - who actually were cut off from all reading activities during their imprison-were analyzed and summarized.

A number of interesting facts came up: There was hardly any desire or possibility to read in KZ-Camps, nevertheless a strong strive for a high cultural level was felt in order to keep the minds sane, such as 'reading as if' in many variations: Reading by heart, citing poems, discussing philosophic questions, imagining recipes, etc. were reported as a means to consenve the taste of reading. But, reading Camp-orders or an occasional piece of paper was not considered reading (only books or newspapers), while writing even a tiny single note was considered writing.

The first readingexperience after liberation was "strange," but only in a few cases was real difficulty encountered in going back to reading. In no case was reading forgotten. Ceneral sadness was expressed about the lost years of reading.

After the release: free newspaper reading was not only expressed as "back to literature," but served as means to the acquisition of the new language (Hebrew). Only very few cases indicated reading encouragement or ambitious book-education of the second generation
\end{abstract}

The acquisition of reading skills can be hampered by emotional, mental, social and other factors. The question asked here is: After all the efforts made learning to read-could this skill be forgotten if not practiced over a period of several years (Verster 1986)? In addition, is this phenomenon intensified by overwhelming emotional trauma, inhuman social conditions and physical torture, such as continuing hunger, slave labor and injuries caused by beatings and other acts of violence?

Consequently further questions arose: Does reading deprivation under the above mentioned circumstances affect the reading interest, whether in the original mother tongue or a newly acquired language? Most Holocaust survivors did not stay in their original homelands after their release and many, or perhaps most of them did not continue to communicate in their mother tongue.

\footnotetext{
*M. Lubliner: Back to Literacy after the Holocaust

1 Acute physical brain damage (stroke etc.) may severely impair reading and language ability.
}

Education for All: Culture, Reading and Information, IASL, 1998 
A further question was related to the educational view of Holocaust survivors on encouraging learning in general and reading in particular on their children-the second generation.

\section{A short survey of the liferature}

Planning the initial research I thought to restrict myself only to the question, whether or not one could forget to read in the narrow sense of reading skills, as acquired at school or even in remedial reading. During the course of research this concept had to be changed and broadened to the perception of literacy in the true sense of the word according to the answers to our questionnaires and the reactions of the interviewees. A very sharp distinction was drawn by them between word deciphering and sentence reading (in this case mostly order-reading) and reading books. Another distinction was made very clearly between reading and writing.

Viewing the literature about this subject, there are of course sources, primary and secondary, relating to culture, music, drama, education and teaching in ghettos, bunkers and camps. ${ }^{2}$ But mostly those sources were neither centered upon reading and writing nor restricted to reading and writing per se, but embedded in more general settings of education, culture etc., without emphasizing the "two R's" as special cultural achievements of the human mind and its impact upon everyone's life.

Nevertheless in a small number of sources we found surprising similarities and even sameness in experiences and imaginary ways prisoners in camps invented in order to keep their striving for a high cultural level alive and their minds sane-especially through reading and writing, and later we could compare them with our findings. It is worthwhile to mention Lotte Adolph (1984, 24, 74, 77. 102, 104, 117), describes learning situations related to reading of children in Terezin, in KZ-Camps and after their release. Other sources relate to school and teaching in ghettos under most dangerous conditions. The young diary author, David Rubinowicz was not aware about writing a diary-he felt that he was just learning, when he filled his five copybooks, saying: "Since the war I learn alone, at home, I long for school, I want to weep...." (Rubinowics 1960, 7) Jews deported from the community of Hamburg to Chetto Lodz (25 October 1941) brought books in their allowed luggage and established there a small, but well organized library Barkai (1985). Often diary literature, like the known one of Anne Frank (1989), Renate Laqueur (1983), and others my throw some light on important aspects of literacy in this period. Writing seemed to be used more often than reading and though only occasionally mentioned, was of utmost significance. Primo Levy (1986) used writing at every opportunity and Victor Frankel (1970) wrote his philosophy and ideas on bits and pieces of paper, while Israel Kaplan gave an interesting example about written expressions of a "secret language" for communication between the prisoners, not to be understood by the SS or the Kapos (Kaplan 1982).

2 Nearly in all the literature about Terezin the intensive cultural activities is described and outstanding people like Rabbi Dr. Leo Baeck and Rabbi Dr. Leopold Neuhaus mentioned. See also Starke (1974); Class (1996). About cultural and educational activities in the KZCamp (near Riga), see Gillis-Carlebach (1990). These are only a few examples. 
Analyzing and comparing the different findings, I want to refer mainly to a book written by Renate Laqueur (1991). As mentioned before the author herself has written a diary during her stay in Bergen-Belsen and later about her experiences there. After her release she went to the United States and wrote her doctoral thesis analyzing 13 diaries of Camp prisoners about their experiences, including her own one-according to various topics, such as: "Hunger," "Death without Dignity," "Love and Eroticism" etc. From the 14 topics chosen by Laqueur, two could be related directly to our study: 1) "Without books I am illReading and Learning"(Laqueur 1991, 67) and 2) "To write as much and as long as possible." (Laqueur 1991, 31)

These highly intellectual topics reassured our first rather vague assumptions, that not only reading per se will be remembered even after long and cruel reading deprivation, but it showed rather convincingly that the drive for cultivated reading, once awakened, may be as indestructible and essential as any other basic strives in human life and living. Furthermore-in several cases it served as substitute for realistic needs, as Karl-Adolph Gross wrote: "after dinner an interesting topic serves as pudding and Russian grammar provides me with the necessary vitamins" (Laqueur 1991, 67).

In contrast to reading, writing served entirely other purposes: The first one-to testify to the experiences in the camps for coming generations-"to shout into the world, what is happening here" (Laqueur 1991, 32) -the other one: to free oneself of the hell of the KZ. Writing was the most free, or rather the only activity proving the prisoners' autonomy. For the tortured women and men it was really a question of human spirit and survival: While writing "lice and fleas will not take over" and "as long as I am writing, I am free" (Laqueur 1991, 31).

According to the foregoing description, the aim of this research was three-fold:

1. To explore whether Reading as an acquired artificial skill could be forgotten, because of the shocking emotional traumas accompanied by inhuman physical conditions (slave labor, serious malnutrition, humiliating living conditions etc.) and often being entirely cut-off from any literacy for a period of several years.

2. To explore whether reading deprivation for the above mentioned reasons would affect the reading interest in a new acquired language (as most Holocaust Survivors did not stay in their original homelands).

3. To explore the educational view of Holocaust-Survivors on generally learning and reading especially of the second generation.

\section{Research procedure}

The research procedure was based mainly on inquiry through questionnaires, with or without the help of an interviewer according to the request of the interviewees or their agreement. ${ }^{3}$ The first ten pioneer interviews were extremely difficult. All the interviewees were inhabitants of two old-age homes. On the one hand, we wanted to get all the necessary information, but on the other, we were obliged to refrain absolutely from applying any pressure on the interviewees. Through an administered pioneer-questionnaire we learnt to deal with a number of problems relating to this type of study: How to find the first connections? How to approach the people? What is a so called "easy" question and

3 I want to thank Gilli, Vered, Tamar, Tehila and Lea for their devoted assistance in this research. 
which one could arise heavy and bitter emotions etc.? But on the whole the quasi simple and objective topic relating mainly to reading and writing, and not directly to Holocaust experiences, often helped them and us to overcome distrust and uncomfortable feelings. Nevertheless, we even got a considerable amount of background information about life in the Ghettos, KZ Camps etc. and a small number of unpublished original documents which may not have been found even in research which is primarily directed to such a purpose. ${ }^{4}$

Following steps were undertaken:

A pre-test questionnaire was compiled and with the assistance of an interviewer was filled out by the above mentioned ten people, in Hebrew, German or English, according to their request.

The questionnaire was changed as a result of their reactions, and sent out to the same people, who filled it out independently. The questionnaire was then edited for style only, and not for its content.

The questionnaire was then sent to 55 addresses: 15 were sent abroad, but according to unforeseen circumstances we could not take them into consideration in this phase of the research. 40 questionnaires were sent to various people in Israel, all over the country (as mentioned before they were filled out independently or with the assistance of an interviewer).

A number of these interviews were recorded with permission.

\section{The Research Tool-Description of the Questionnaire}

The questionnaire was divided into several parts:

The first part is an introductory letter that explains the purposes of the research and is formulated in a way to make the interviewees feel at ease.

The second part deals with background information about home, family and education, with special emphasis on reading environment and reading encouragement at home.

Part three deals with the circumstances just before the outbreak of the war, such as age, the learning institution visited at this time etc. Special consideration was given to personal reading interests. Other questions were related to known languages, such as Hebrew, Yiddish etc.

Part four deals with the war period-circumstances that led to imprisonment, Ghetto or Camp experiences, possibility of reading, writing, praying, learning in these places, with special emphasis on the circumstances that enabled reading or "reading substitution," desire to read in spite of the severe conditions and feelings about the lack of opportunities for literate activities.

In part five the participant was asked for information about the circumstances after the release with special emphasis on feelings about coming back to reading and writing,

4 Three of the unpublished sources can already be mentioned: Meir, P.: In the Arms of Death (Hebrew), 34 p., Penina: Memoirs (Hebrew), 12 p. and Saba W.: Vorwort, Kindheit, Westerbork - Theresienstadt - Auschwitz, Treblinka (Cerman), $17 \mathrm{p}$. 
material available and possible literate opportunities, and on the ways and circumstances of learning the new language.

Part six deals with the survivors' attitude to the education of their children (second generation), the reading encouragement they gave them and their ambitions to direct them to academic or literate achievement.

In the last part we asked for additional names of persons, possibly ready to participate in this research, for documents and any information the interviewee was ready or interested in bringing to our attention.

\section{The interviewees}

Needless to say that our target population were Holocaust survivors. Under this heading a wide range of people is included. People of different ages, from different countries and family-environments and with different life-experiences, before, during and after the war. From the point of view of research, we considered this group as "available population," which is by no means a so-called statistical randon example or an experimental group.

The first people who were interviewed, gave us further names; others we got through personal connections, through careful, quiet inquiry, etc. One name brought the other. We tried to contact any survivor willing to cooperate.

\section{Analysis of questionnaires according to following criteria:}

1. Age, place of birth, religious (reading) background and school experience prior to the war; KZ-camp/ghetto/bunker experiences; memory of childhood books, desire to read in camps, first reading experience after deliberation.

2. Learning, Language and Reading experience in the new language, attitude toward reading and literacy in comparison with childhood.

3. Center of gravity in reading education of the second generation.

\section{Analysis of written and recorded answers}

The answers in the questionnaires were divided into categories, and according to the nature of each category analyzed from a qualitative or a quantitative aspect ${ }^{5}$ and then finally summarized. So far 40 questionnaires (of 55 ) were included in this summary. It is important to state that not all the categories were defined in advance, but emerged as a result of the answers to the open questions therein.

One factor must be emphasized from the very beginning: The personal experiences of Holocaust survivors differ in many ways. On the one hand, these experiences are beyond one's grasp, and in a way impossible to describe. On the other hand, they are hardly comparable-as the various experiences are highly individual (A few examples connected to reading and writing will be added in the appendices).

5 About quantitative and qualitative categories see Chall (1967, chap. 10). 


\section{Results (Summary of data of $\mathbf{4 0}$ interviewees)}

Table 1: Age (birth date) ranges from 1905-1936

\begin{tabular}{rr}
$1905-1914$ & 4 \\
$1915-1919$ & 13 \\
$1920-1929$ & 15 \\
$1930-1936$ & 8 \\
\hline
\end{tabular}

Interpretation: Most interviewees were in the age-groups 1920-1930; i.e., 19-29 years old at the beginning of world war II.

\begin{tabular}{lr}
\hline Table 2: & Place of birth \\
\hline Czechoslovakia & 5 \\
Germany & 6 \\
Hungary & 2 \\
Poland & 23 \\
Rumania & 3 \\
Russia & 1 \\
\hline
\end{tabular}

Interpretation: Most interviewees came originally from east-Europe and more than 50\% from Poland.(So far we did not find any statistical registration of the homeland of the Holocaust-survivors in Israel or elsewhere).

\begin{tabular}{ll}
\hline Table 3: $\quad$ Gender \\
\hline Women & $19(6)-25$ \\
Men & $11(4)-15$ \\
Number of answers & $30-40$ \\
\hline
\end{tabular}

Interpretation: Most interviewees were women (For some unknown reasons 10 people did not write the answer, and we deciphered the answers according to the personal names).

\begin{tabular}{lc}
\hline Table $4:$ & Father's occupation \\
\hline Religious task & 2 \\
Trade & 19 \\
Teacher & 3 \\
Craft & 4 \\
Industry & 4 \\
Other & 4 \\
(No exact answers) & 4 \\
\hline
\end{tabular}

Interpretation: Nearly half of the interviewees' fathers made their living from some sort of trade; but also mentioned are a printer, a bookbinder, two tailors and other professions. 


\section{Table 5: Mother's occupation}

\begin{tabular}{lc} 
Housewife & 24 \\
Trade & 3 \\
Teacher & 0 \\
Craft & 4 \\
Industry & 2 \\
(No exact answers) & 7 \\
\hline
\end{tabular}

Interpretation: Seven Interviewees did not answer, because they were too young to remember; but obviously the majority of married women were housewives.

\begin{tabular}{lc}
\hline Table $6:$ & $\begin{array}{l}\text { Schooling (Total number of years of } \\
\text { schooling before the war; without } \\
\text { considering the age) }\end{array}$ \\
\hline $1-2$ years & 5 \\
$3-6$ years & 9 \\
$7-9$ years & 18 \\
$10-12$ years & 3 \\
$13+$ years & 1 \\
Unknown & 4
\end{tabular}

Interpretation Most interviewees had 7-9 years schooling, which means at least "Volksschule" or 4 years elementary school and a number of middle or high school classes, before the war. With the enlargement of the study and the number of interviewees, the correlation between the age at outbreak of the war and years of schooling will be essential.

\section{Table 7: $\quad$ Reading encouraged and cultivated at home}

\begin{tabular}{lr} 
Not particular & 6 \\
Much & 12 \\
Very much & 14 \\
Particularly much & 8 \\
\hline
\end{tabular}

Interpretation: It is worth mentioning that all interviewees answered this question; according to the interviewers' notes, rather enthusiastically. The overall impression is that reading was an important factor in most families. 


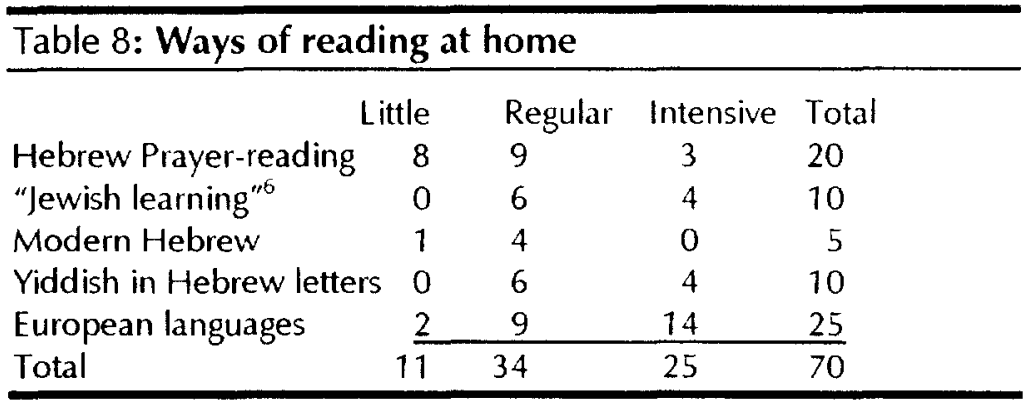

Interpretation: From the above summary we can see that in most homes at least one kind of reading was regularly or intensively cultivated, mostly in more than one language. Reading in European languages was more intensive than prayer reading.

Table 9: Books and Authors remembered (alphabetic lists; part.)

\section{Authors}

Shalom Aleichem (2), Aristotie, Balzac, Ben Chur, Ch.N. Bialik, V. Baum, L. Dostojewski (2), L. Feuchtwanger, A. Feuerstein, Anatole France, J. W. von Goethe (2), H. Heine, Victor Hugo, Kellermann, S. Lagerlöf, Jack London (2), Thomas Mann, Karl May, Mitzkowitz, Y.L. Perez, Pinsker, Pushkin, W. Shakespeare, Schankoritz (2), F. Schiller, U. Sinclair, B. Spinoza, Stobetzki, L. Tolstoi (3), E. Udschakowa, Uland, Emil Zola, Stefan Zweig (2).

\section{Books}

Anna Karenina (2), Auto-Emancipation, Cone with the Wind, Heidithe mountain girl (2), Kaspar Hauser, Martin Oden (?) The Heart (3), The Jew Suess, The picture of Dorian Gray, The "Rik-Pik" Club (2), The three Musketeers, War and Peace (3), Truth, Women

(Some of the books/authors were mentioned twice or three times by different interviewees; the numbers put in brackets).

Interpretation: These answers were given spontaneously. A few of the interviewees added later, that "they didn't even know that they could remember so many books and authors from child and adulthood."

6 Jewish or "Hebrew Learning" usually refers to Talmud study, and the analytical and critical reading of its Hebrew or Aramaic written text. 
Table 10: Desire or possibility to read in

KZ-Camps etc.

$\begin{array}{lr}\text { Absurd question } & 4 \\ \text { Not at all } & 19 \\ \text { Not particularly } & 3 \\ \text { Much } & 9 \\ \text { Particularly much } & 5\end{array}$

Interpretation: This question arose strong and in some cases even aggressive reactions. The majority of these answers were negative, but it is important to state that about a third of the interviewees gave definitely positive answers. In a number of answers, differences in possible reading situations between ghettos and camps were stated and in addition general opinions about reading and writing were expressed

In addition, interviewees did not classify occasionally reading a piece of newspaper, written instructions, praying from the prayer book etc. as "real reading." Only "book reading" was considered as reading. But writing on smallest pieces of paper was mentioned by a number of interviewees as "writing per se."

\section{Table 11: Reading after release}

$\begin{array}{lr}\text { Forgotten } & 0 \\ \text { Temporary difficulty } & 9 \\ \text { No difficulty } & 13 \\ \text { Very natural } & 14 \\ \text { More conscious } & 4\end{array}$

Interpretation: From the above we see, that in not one single case reading was forgotten, and only in rather few cases temporary difficulty was felt. Most of the interviewees got back to reading with no difficulty and even in a very natural way, as if they had never stopped reading.

\section{Table 12: Emotions about "first reading" after release}

Grief about the period without reading 3

Envying people who did not suffer from

Reading interruption

Enthusiasm about beauty and pleasure of reading 7 Hate of written material in former language $\quad 5$ Can't remember

No answer 12

Interpretation: Not all the interviewees related to this question. A quarter of the answers seem to express indifference. But the remaining answers express strong emotions connected to the very act of reading. 


\section{Table 13: Interests in special books after the release (alphabetic lists; part.)}

Zion's love, A. Mapu; Memorial books about the Holocaust (2); Biographies (2), Sch. J. Agnon, Ch. N. Bialik, L Tolstoi, Newspapers of all kinds.

Interpretation: Besides these sporadically remembered books, nearly all interviewees who related to this question mentioned newspaper reading, which was mostly allowed in the camps. But even in rare cases, when newspapers were available, they were strictly censored. Therefore a so-called "hunger for news" and free newspaper reading was expressed as "back to literature." (Some of the books/authors were mentioned twice or three times by different interviewees; the numbers put in brackets).

\begin{tabular}{lc}
\hline Table 14: & $\begin{array}{l}\text { Institutes helping to acquire the new } \\
\text { language (Hebrew) }\end{array}$ \\
\hline None & 5 \\
Ulpan7 & 3 \\
Evening classes & 18 \\
University & 1 \\
Newspapers & 11 \\
Others & 2 \\
\hline
\end{tabular}

Interpretation: Only a very small number of interviewees learnt the new language (in our sample, Hebrew) in an UIpan, where they could devote themselves entirely to language acquisition. Most of them learnt either in evening classes or "by the way" with no special help. Acquaintance with former Old Testament Hebrew was an advantage, but not really helpful for spoken modern Hebrew, because of the profound differences in vocabulary, pronunciation and grammar. But reading newspapers ${ }^{8}$ seemed very helpful in learning to read and communicate in the new language.

\begin{tabular}{lc}
\hline Table 15: & Number of (reading)-languages known \\
\hline Only one & 0 \\
Two & 16 \\
Three & 12 \\
Four & 4 \\
More & 5
\end{tabular}

Interpretation: In nearly half of the cases at least two languages were known after the Holocaust, but more than a half of the questioned population spoke 3-4 or even more

7 Ulpan is special day-class to learn Hebrew, sometimes with boarding-house conditions. Students do not work during the Ulpan-period, generally lasting 3-6 month.

8 Newspapers served as substitute for "learning institutes" and for literacy. About The lewish D.P. press in Germany as "a dazzling variety of newpapers and magazines in Yiddish, Hebrew, German and English" see Rosensaft (1957). 
languages. The mentioned languages: Czech, English, German, Hebrew, Hungarian, Polish, Portuguese, Rumanian, Russian, Spanish, Yiddish.

\section{Table 16: Education of the Second Generation}

$\begin{array}{lr}\text { No answer } & 15 \\ \text { No special care } & 6 \\ \text { Effort without pressure } & 5 \\ \text { (Very) ambitious } & 14\end{array}$

Interpretation: It seems that the dilemma about the second generation and their education is somehow of painful concern, maybe caused by unsuitable questions. The first 15 interviewees did not answer at all. As we became aware of the problem, we altered the questions and consequently got more answers which indicate reading encouragement and even ambitious book-education.

\section{Summary}

According to the aims of this research we were looking for answers to the following questions:

1. Whether reading as an acquired artificial skill could be forgotten under certain circumstances,

2. Whether reading deprivation could affect the reading interest in a new acquired language;

3. What is the educational view of Holocaust survivors on encouraging especially reading of the second generation.

\section{Initial results:}

1. Experiences during the Holocaust are extremely different.

2. First reading-experience after liberation was "strange" only in a few cases, and in no case forgotten.

3. The thought about books helped in a few cases to better feelings during interment.

4. In most cases there was a strong desire to learn the new language, often resulting in outstanding achievements.

5. Much insecurity was expressed about the issue of education of the second generation.

\section{Goals for further research:}

1. To continue the research through enlarging the Hebrew and German speaking population and to extend it to English (and French) speaking Holocaust survivors.

3. To include non-Jewish Holocaust survivors in the research.

4. To computerize the details:

About the various experiences of the survivors,

About the reading experiences in camps, such as reading desire, happiness about reading possibility, reading avoidance, first reading "strangeness," prayer and bible-reading in the camps etc. 
Special thanks to Prof. S. Simpson, present Director of the Haddad Center, Bar-llan University and to Mrs. M. Steiman from the Magbioth, Bar-Ilan University for helping with the English version.

\section{References}

Adler, H.G (1960). Theresienstadt, 1941-1945, Das Antlitz einer Zwangsgemeinschaft: Geschichte, Sociologie, Psychologie. Tübingen: J.C. B. Mohr (Paul Siebeck).

Adoiphs, Lotte (1984). Kinder in Ketten: Kinderschicksale in Chettos und in Konzentrationslagern. Duisburg: Walter Braun Verlag.

Barkai, Abraham (1985). Between East and West-Jews from Germany in Chetto Lodz. Yad Vashem Studies, 16, 219-264.

Chall, Jeane (1967). Learning to read-the great debate. New York: McGraw Hill.

Frank, Anne (1989). Die Tagebücher der Anne Frank: Historisch-kritische Ausgabe. Amsterdam: Niederlandisches Staatliches Institut für Kriegsdokumentationen.

Fraenkel, Josef (1957). The Cultural Liberation of Belsen. In Belsen (pp.164-176). Tel Aviv: Irgun Sheerit Hapleita.

Frankel, Victor (1981). Men's search for meaning (Hebrew). Tel-Aviv: Dvir

Freeden, Herbert (1964). Jüdisches Theater in Nazideutschland. Tübingen: J.C.B. Mohr (Paul Siebeck).

Friedländer, Saul (1998). Nazi Germany and the Jews: TheYears of Persecution 1933-1939. Tel-Aviv: Am Oved (Hebrew).

Gillis-Carlebach, Miriam (ed) (1990). Jüdischer Altag als Humaner Widerstand 1939-1941. Hamburg: Verein für Hamburgische Geschichte.

Glass, Martha (1996). Jeder Tag in Theresin ist ein Ceschenk: Die Thereisenstadter Tagebücher einer Hamburger Jüdin 1943-1945. Herausgegeben von Barbara Müller-Wesemann. Hamburg: Die Landeszentrale für politische Bildung.

Goldschmidt, Joseph (1984). The Holocaust and the Jewish teacher. In A. Wassertiel (ed.), Chapters of Thought and Education (in Hebrew). Jerusalem: Ministry of Education, Department of Religious Education; Tel-Aviv: Ghetto Fighters' House.

Kaplan, Israel (1982). Jewish Folk-Expressions under the Nazi Yoke (Yiddish). Tel-Aviv.

Katzburg, Nathanel (ed.) (1984). Rescue during the Holocaust (Hebrew). Ramat-Gan: University Press.

Kleinman, Judith (ed.) (1988). Letters from "No-Where"-Last letters from Jews under Nazi-Rule (Hebrew). Jerusalem: Yad Vashem.

Laqueur, Renate (1983). Bergen-Belsen Tagebuch 1944-1945. Hannover: Fackeltrager Verlag. 
Laqueur, Renate (1991). Schreiben im KZ: Tagebücher 1940-1945 (from the English by M. Dreisbach. Hannover: Niedersächsischen Landeszentrale für politische Bildung.

Levy, Primo (1986). Survived in Auschwitz (Se Questo E Un Homo) New-York: Summit Books.

Lubliner, $M$ (1957). Jewish Education in Belsen. In Belsen (pp. 156-168). Tel Aviv: Irgun Sheerit Hapleita.

Rubinowics, Dawid (1960). Pamietnik Dawida Rubinowicza. Warsaw: Ksiazka, Wiedza.

Rosensaft, Josef (1957). Our Belsen. In Belsen (pp. 24-51). Tel Aviv: Irgun Sheerit Hapleita.

Starke, Käthe (1975), Der Führer schenkt den Juden eine Stadt-Bilder, ImpressionenReportagen-Dokumente. Berlin: Hande \&Spenersche Verlagsbuchhandlung.

Strang, Ruth (1942). Exploration in Reading Patterns. Chicago: The University of Chicago Press.

Vester, Frederic (1986). Denken, Lernen, Vergessen. Was geht in unserem Kopf vor, wie lernt das Gehirn und wann lässt es uns im Stich. München: Deutscher Taschenbuch-Verlag.

Walk, Joseph (1975). The Education of the Jewish Child in Nazi Germany-The Law and its Execution (Hebrew). Jerusalem: Yad Vashem /Leo Baeck Institut.

Warhaftig, Zorach (1984), Refugee and Remnant-Rescue Efforts during the Holocaust (Hebrew). Jerusalem: Yad Vashem/Oth Vaed.

Wohlgemuth, J.A. (1954). Fragt immer: Gut oder Böse? Kulturkritische Betrachtungen und Anregungen für Zwecke der Volkerverstandigung. Zürich: Overflag Arzenu. 


\section{Appendices (Translations from German)}

\section{Appendix 1: Orders concerning letter-writing in KZ-Camps: (letter in private possession), Concentration Camp Sachsenhausen, Oranienburg near Berlin}

Every prisoner is entitled to write monthly 2 letters... not more than 4 pages of 15 lines. Otherwise the letter will not be sent

Here you have to sign that you will bequeath your bank-account to the Cestapo ...

The Postzensurstelle (the post-censor-office).

\section{Appendix 2: "Reading and teaching by heart"}

Written testimony (1973) by Betty Willner from Fürth about KZ-Camp Jungfernhor near Riga (in: M. Gillis Carlebach, pp. 113-114):

"...As most important and most urgent need among other problems, and after the inspection of the KZ-conditions Rabbi Carlebach's uppermost concern was to care for the children. He understood immediately that the bitter cold (below -50 centigrade), the inhuman hygienic conditions and above all the nagging, never satisfied hunger-all this will have the worst influence on the school-children.

In the shortest time he succeeded to gather those camp-prisoners who could possibly teach the children. Betty Willner was chosen to prepare a timetable for the curriculum. "It was the tiniest plan ever written on a very little scrap of torn paper. There were no books and no writing material. The children were taught by heart: languages, geography, math and of course Jewish subjects by Rabbi Carlebach himself. He sang with the children chapters of the Psalms with his warm voice and stimulated the children to active participation in learning: sometimes 10 minutes only and sometimes half an hour or an hour, according to the circumstances. Of cause all this was illegible...." 
Appendix 3:

Everyone was an author: (according to questionnaire No. 38)

"In KZ-Camp we were a group of 6 girls; after work we tried to talk about books we read at home or at school... everyone had to present a certain author... We chose an interesting subject or a book-title and everyone (every 'author') made her critical comments according to the author's opinion she had to present."

\section{Appendix 4: Desire to learn as quick and as much as possible (Letter in private possession):}

The survivor took the examination for his matriculation in all the required subjects-7 month after his release of $41 / 2$ years from most traumatic $K Z$-experiences: He wrote to his cousins: "I did it, I did it! I did the Matric!" He was examined by Cerman professors of Theology in Hebrew, and got by chance Psalm Number 24. To their astonishment he knew to recite it by heart... . 